\title{
COMPLETE HYDATIDIFORM MOLE WITH A COEXISTENT FETUS DIAGNOSED BY MAGNETIC RESONANCE IMAGING
}

\author{
Hye-In Sung, MD¹, Young-Ok Shin, MD¹, Hyeonkyeong Yeon, MD¹, Oh-Young Lee, MD', Eun-Hwan Jeong, MD ${ }^{1,2}$ \\ ${ }^{1}$ Department of Obstetrics and Gynecology, Chungbuk National University Hospital; ${ }^{2}$ Medical Research Institute, Chungbuk National University College of Medicine, \\ Cheongju, Korea
}

Hydatidiform mole with coexistent fetus is very rare, arising about 1 in 20,000 to 100,000 pregnancies. There are limited data to guide the management and treatment. Also it is a dilemma to decide continuation or termination of pregnancy. We experienced a case of hydatidiform mole with a coexistent fetus which was diagnosed with magnetic resonance imaging in a woman of 13th weeks of pregnancy. After termination of pregnancy, the patient treated with prophylactic chemotherapy. We report the case with a brief review of literature.

Keywords: Hydatidiform mole; Twin; Magnetic resonance imaging

정상임신과 포상기태를 동반한 쌍태임신은 임신 20,000 에서 100,000 건당 한 건의 빈도로 보고되고 있다[1]. 정상태아와 포상기태 가 공존하는 경우에 단순 포상기태와 비교하여 내과적인 합병증이 더 심하고 지속성 임신성 융모종양으로 진행될 위험이 높다고 보고되어 있기 때문에 조기진단이 중요하다. 하지만 그 희귀성 때문에 진단이 어 렵다.

초음파가 여전히 일차적인 선별검사 방법이지만 초음파상으로는 부 분침윤을 확인하기 어려우며 감별진단을 위해 다른 영상 도구가 필요 한 경우도 있다. 컴퓨터단층촬영술과 자기공명영상 장치가 진단에 종 종 사용되고 있으며 자궁근층과 자궁주위 조직의 종괴나 혈관 확장, 조 직의 괴사 출혈을 찾는데에도 유용하다. 특히 생존태아가 존재하는 경 우 더 상세한 진단 및 평가가 필요한 경우에 자기공명영상장치의 발전 으로 인해 임신 시 자궁과 복부 내부의 추가적인 정보를 더 얻을 수 있 게 되었다[2].

저자들은 임신 13주에 태아와 공존한 포상기태를 골반 자기공명영 상으로 진단하여 임신을 종결한 1 예를 경험하였기에 간단한 문헌고찰 과 함께 보고하는 바이다.

\section{증 례 \\ 환 자: 임 $\mathrm{O}$ 규, 28세 \\ 출산력: $1-0-0-1$}

가족력 및 과거력: 어머니(고혈압)

주호소: 무월경 13주의 질출혈

월경력: 초경은 13세 때 시작하였고, 월경주기는 규칙적이며 지속기간 은 5일 정도, 양은 보통이었으며 생리통은 약간 있었다.

현병력: 자연임신 후 개인 산부인과에서 산전 진찰 중으로 첫 번째 임 신 때보다 배가 많이 부른 듯 했고 입덧 증세도 심했다. 특별히 문제 있 다는 애기 듣지 못했으나 임신 10주경과 12주경에 속옷을 흠뻑 적실 정도의 질출혈이 있고 이후로도 소량의 질출혈이 지속되었다. 임신 13 주에 개인 산부인과에서 초음파검사 후 태아는 이상 없으나 태반 조직 이외에 벌집모양의 종괴가 보인다고 본원 외래로 전원되었다. 본원 외

Received: 2011.9.23. Revised: 2012.4.17. Accepted: 2012.4.24. Corresponding author: Eun-Hwan Jeong, MD Department of Obstetrics and Gynecology, Chungbuk National University Hospital, Chungbuk National University College of Medicine, 52 Naesudong-ro, Heungdeok-gu, Cheongju 361-711, Korea Tel: +82-43-269-6052 Fax: +82-43-275-7359

E-mail: jeongmed@chungbuk.ac.kr

This is an Open Access article distributed under the terms of the Creative Commons Attribution Non-Commercial License (http://creativecommons.org/licenses/ by-nc/3.0/) which permits unrestricted non-commercial use, distribution, and reproduction in any medium, provided the original work is properly cited.

Copyright $\odot$ 2012. Korean Society of Obstetrics and Gynecology 


\section{KOREAN JOURNAL OF OBSTETRICS \& GYNECOLOGY}

KJOG Vol. 55, No. 6, 2012

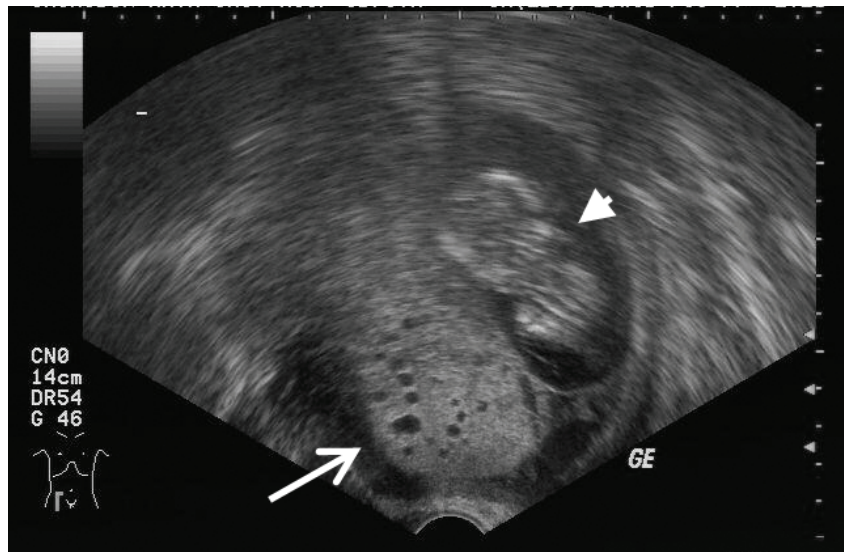

Fig. 1. Transavaginal ultrasound imaging demonstrates multicystic hyperechoic mass (arrow) with coexistent living fetus (arrow head).
래에서 시행한 복부초음파와 질초음파에서 두정둔부길이 $5.3 \mathrm{~cm}$ 크기 의 태아가 관찰되었으며 이는 주수에 맞는 크기였다. 태아 심음은 정상 적으로 관찰되었고 외부 기형은 관찰되지 않았다. 자궁의 왼쪽으로 낭 종을 가진 수종성 변화를 보이는 덩어리 양상이 관찰되었다(Fig. 1). 절 박유산, 태반종양, 부분포상기태 의증하에 골반 자기공명영상 촬영을 시행하였다. 골반 자기공명영상 촬영상 자궁강내 오른 쪽으로는 정상 임신낭이 보이고 그 안에 정상태반과 태아가 관찰되었다. 태아는 외부 기형이 없으면서 주수에 합당한 소견을 보였다. 지궁강 내부 왼쪽으로 정상 임신낭과 구분된 고음영과 저음영이 혼합된 태반모양의 덩어리가 관찰되었다(Fig. 2). 정상태아와 포상기태가 동반하는 쌍태임신이 진단 되었고 예후와 위험성에 대한 충분한 설명과 상의 후 임신을 종결시키 기로 결정하여 흡입소파술 시행 위해 입원하였다.

이학적 소견: 입원 시 혈압은 120/70 mm Hg, 맥박은 72회, 호흡수는
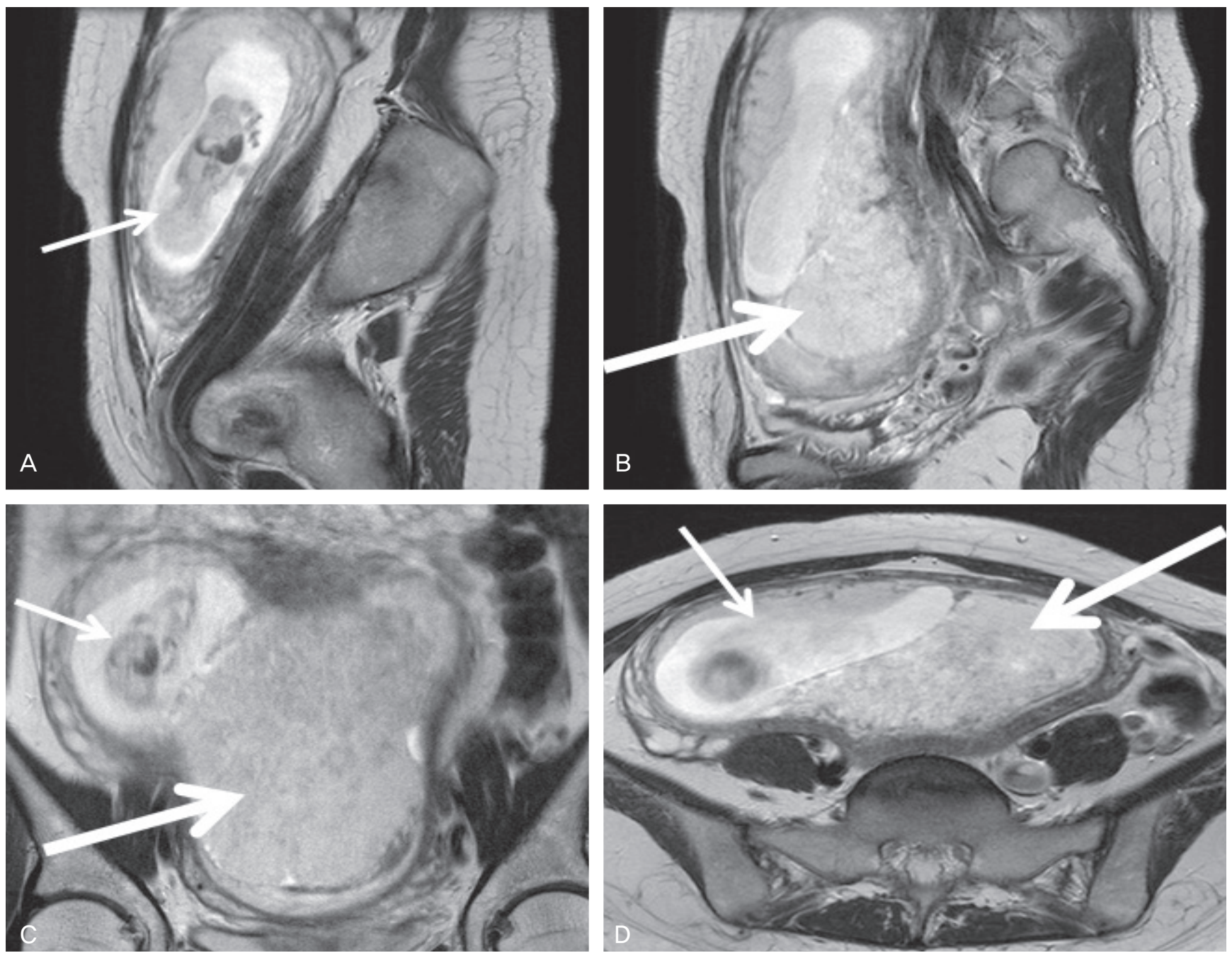

Fig. 2. Magnetic resonance imaging demonstrates normal fetus (thin arrow) of 13 weeks of pregnancy with anterior wall placenta at the right upper portion of uterus, and multiloculated cystic mass (thick arrow) with high signal intensity on T2-weighted image at the left inferior portion of the uterine cavity. (A, B) Sagittal images. (C) Coronal image. (D) Axial image. 


\section{KOREAN JOURNAL OF OBSTETRICS \& GYNECOLOGY}

Hye-In Sung, et al. Complete H-mole with coexistent fetus

분당 20회, 체온은 $36.5^{\circ} \mathrm{C}$ 였다. 신장은 $167.8 \mathrm{~cm}$, 체중은 $66.8 \mathrm{~kg}$ 이었 다. 청진상 심장과 폐 이상소견은 없었다.

검사 소견: 본원 외래 처음 방문 시 혈색소가 $10.1 \mathrm{~g} / \mathrm{dL}$, 백혈구가 $5,300 / \mu L$, 헤마토크리트는 $29.6 \%$ 였고, B형간염항원은 음성, B형간염 항체는 양성, 매독검사가 음성이고 혈액형은 Rh(+) A형이었다. 혈청 인 간 융모생식샘자극호르몬은 $545,000 \mathrm{mU} / \mathrm{mL}$ 이었다. 요검사, 출혈 및 혈액응고검사, 간기능검사, 신기능검사는 정상이었다. 갑상선기능검사 는 T3 $155 \mathrm{ng} / \mathrm{dL}$, free T4 $1.10 \mathrm{ng} / \mathrm{dL}$, thyroid stimulating hormone $0.13 \mathrm{ulU} / \mathrm{mL}$ 이었고 갑상선항진증의 임상적 증세는 없었다. 심전도검 사와 흉부방사선검사는 정상이었다. 삼중표지물질검사 및 양수천자검

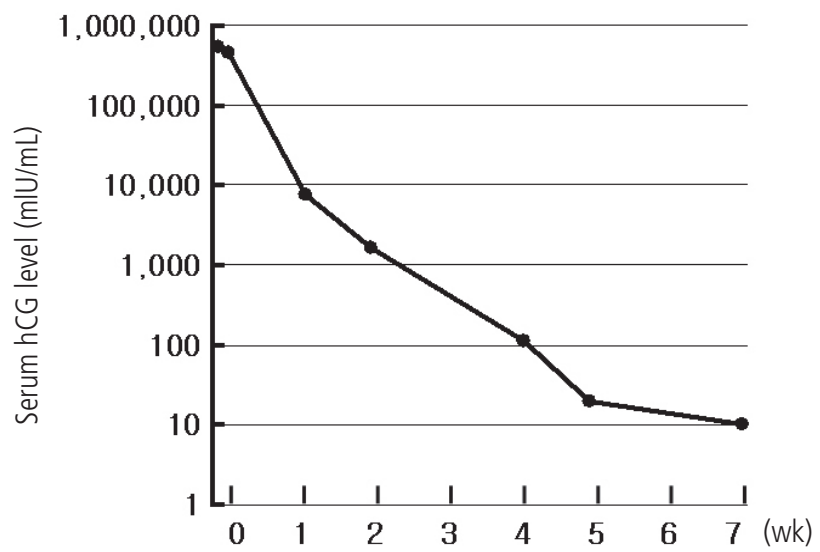

Fig. 3. Serum human chorionic gonadotropin (hCG) level before and after treatment.

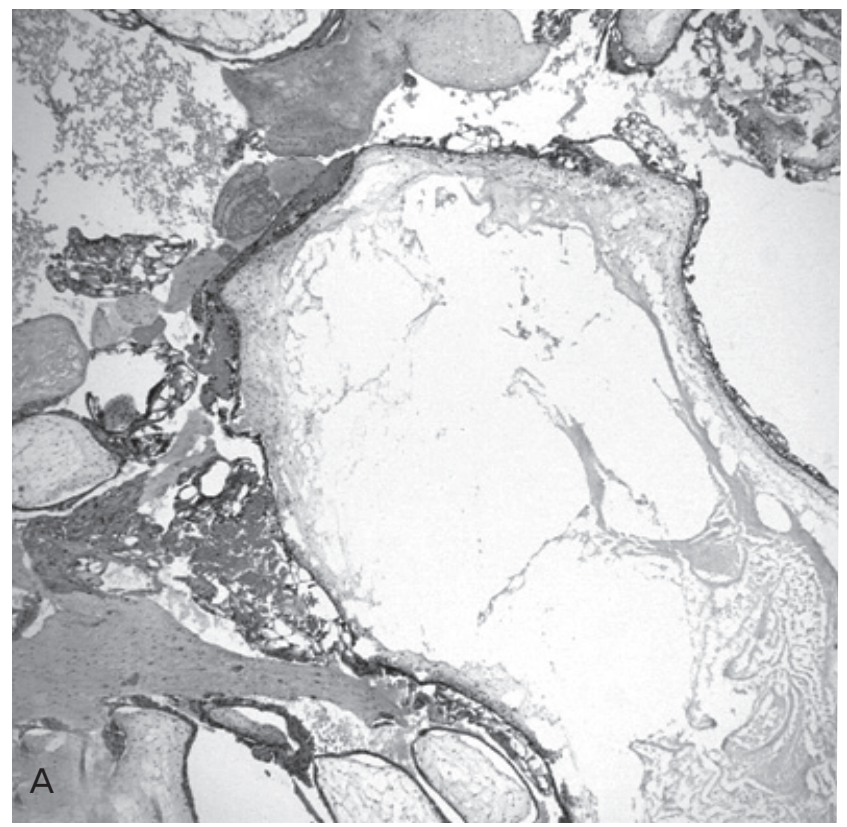

사는 시행하지 않았다. 입원 시 복부초음파상 자궁내부에 $10 \times 10 \mathrm{~cm}$ 크기의 눈보라모양이 관찰되었으며 자궁의 오른쪽으로 두정둔부길이 $7 \mathrm{~cm}$ 크기의 정상태아가 관찰되었다.

수술 소견: 수술 하루 전 오후 10시에 라미나리아 1개, 수술일 오전 8 시 반에 라미나리아 3개 삽입하였고 수술장에서 수면마취하에 자궁내 흡입소파술을 시행하였다. 복부 초음파 관찰하에 흡입소파술로 아래쪽 에 있는 포상기태 조직을 제거하였고 이후 겸자와 큐렛으로 태아와 잔 류태반 조직을 제거 후 수술을 마쳤다. 수술 중 실혈량은 $500 \mathrm{~mL}$ 가량 예상되었다.

수술 후 경과: 수술 후 활력징후는 정상이었으며 소량의 질출혈 동반 되는 상태로 수술 후 3 시간 동안의 질출혈량은 $40 \mathrm{~g}$ 이었다. 수술 직 후 혈색소는 $7.8 \mathrm{~g} / \mathrm{d} L$ 으로 농축적혈구 2파인트 수혈하였으며 수혈 후 혈색소는 $9.1 \mathrm{~g} / \mathrm{dL}$, 수술 1 일 째 혈색소는 $11.9 \mathrm{~g} / \mathrm{dL}$ 이었다. 수술 직 후 혈청 융모생식샘자극호르몬 수치는 $456,000 \mathrm{mlU} / \mathrm{mL}$ 이었다. 수술 후 1일째부터 예방적 단일 약제 항암 치료(methotrexate $1.0 \mathrm{mg} / \mathrm{kg}$, citrovorum factor $0.1 \mathrm{mg} / \mathrm{kg}$ )를 시행하였다. 첫 번째 항암요법 주기 마 지막 날인 수술 후 8 일째 시행한 혈청 융모생식샘자극호르몬은 7,500 $\mathrm{mlU} / \mathrm{mL}$ 으로 감소되어 있었다. 수술 후 9일째에 환자는 특별한 합병증 없이 수술 후 9일째에 퇴원하였다.

퇴원 후 추적검사: 수술 후 예방적 단일 약제 항암 치료는 한 주기만 시행하였고 이후 외래에서 혈청 융모생식샘자극호르몬 수치를 경과추 적하였다. 수술 후 48 일(7주)째 외래에서 시행한 혈청 융모생식샘자극 호르몬은 $10 \mathrm{mlU} / \mathrm{mL}$ 으로 정상 수치로 감소되었고 이후 매월 한 번씩 6 개월간 검사하여 정상 수치를 유지하였으며 현재까지 특이한 합병증 없이 잘 지내고 있음을 확인하였다(Fig. 3).

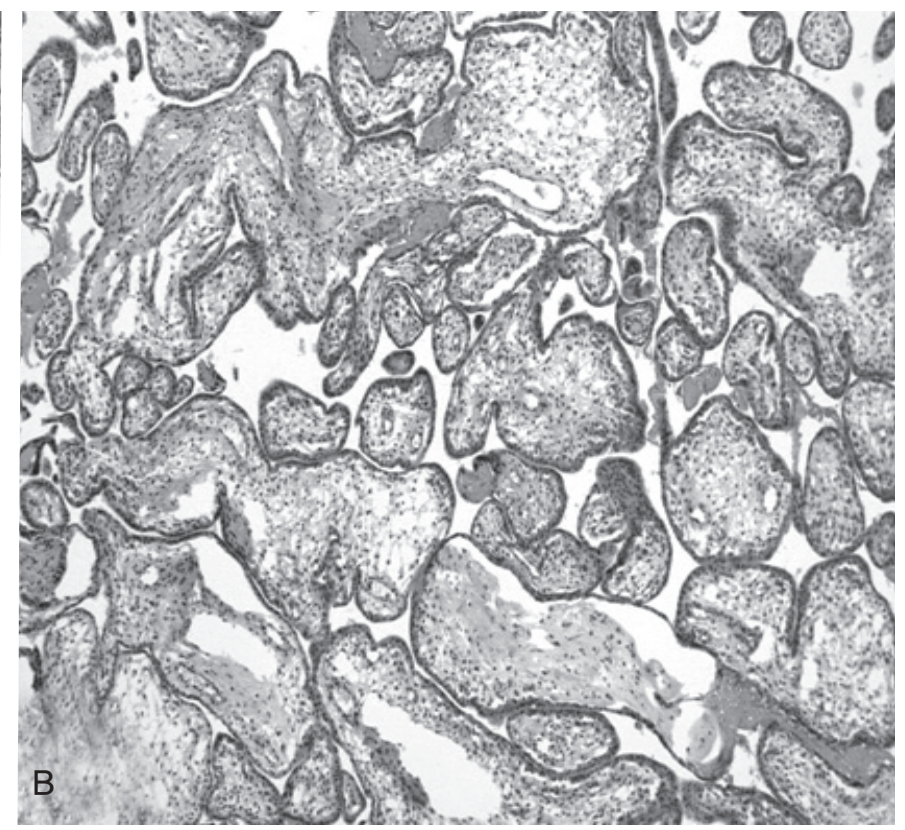

Fig. 4. Microscopic examination shows hydatidiform swelling of the chorionic villi, trophoblastic proliferation, and absence of stroma or blood vessels, which are consistent with complete hydatidiform mole, from molar tissue (A), and normal chorionic villi from coexistent fetus (B) (H\&E, $\times 400)$. 


\title{
KOREAN JOURNAL OF OBSTETRICS \& GYNECOLOGY
}

\author{
KJOG Vol. 55, No. 6, 2012
}

병리조직학적 소견: 현미경검사상 정상태아측의 태반은 정상적 소견 을 보였으며(Fig. 4A) 포상기태 부위는 융모의 수종성 변성 등 완전포 상기태의 전형적인 병리조직학적 소견을 보였고 악성변화는 관찰되지 않았다. 면역화학염색 결과 태아측은 CD 31 (+), P57 (+)이고 포상기 태 조직은 CD 31 (-), P57 (-)이었다. 광학현미경 소견 및 면역화학염 색 결과 두 조직의 소견이 완전히 달라 정상태반과 완전포상기태의 다 태임신으로 진단하였다(Fig. 4B). 태아조직과 포상기태 조직의 유전학 적 분석 및 핵형 분석은 시행하지 않았다.

\section{고 찰}

포상기태와 동반된 쌍태임신은 과거에는 주로 계류유산이나 불완전 유산의 치료목적으로 유산시킨 후 병리조직학적 검사상 확인되는 경우 가 대부분이었다. 그러나 임신 초기와 중기에 산전초음파 시행이 보편 화되고 초음파와 세포유전학의 발달로 산전에 태아와 공존하는 포상기 태의 진단이 가능해졌다. 초음파검사로 완전포상기태와 동반된 쌍태임 신은 많은 반향성을 보이는 눈보라모양의 태반과 정상태반을 구분하여 진단할 수 있고 보통 임신 12-14주에 진단된다. 반면 부분포상기태와 동반된 쌍태임신은 두 명의 태아를 확인할 수 있고 하나는 구조적으로 정상이나 다른 하나는 대개 삼배체성이어서 선천기형과 자궁내 발육부 전이 있고 보통 임신 15-20주에 진단된다[3]. 그러나 여전히 생존태아 의 심박수를 관측하고 정상임신으로 오인함으로써 진단이 지체될 수 있으며 공존하는 태아와 별개의 낭성변종을 보이는 종괴가 보이는 경 우 이상태반부착, 혈종형성, 태반종양으로 생각하기 쉬우므로 주의를 기울여야 한다. 초음파상 변형된 수태물을 가진 계류유산이나 자궁근 종 및 자궁내 혈종을 동반한 정상임신에서도 비슷한 모양을 보이므로 초음파만으로 진단될 수 있는 것은 아니고 반드시 인간 융모생식샘자 극호르몬 수치와 임신과 관련된 합병증 등을 고려해서 진단해야 한다. 일단 초음파로 포상기태와 함께 생존태아가 확인되면 태아의 기형유무 를 면밀히 검사한 후 임신지속 여부를 결정해야 한다.

포상기태의 발생빈도는 지역에 따라서 매우 다양한 양상을 보여주고 있어서, 미국과 유럽에서는 인종에 따라 차이가 있지만 1,000 임신당 1 에서 2 명으로 보고되고 있고, 히스패닉과 아메리카 인디언에서는 더 빈번하다고 보고되고 있다[4]. 한국에서 포상기태는 1970년대 1,000 분만당 40명에서 1990 년대 1,000 분만당 2 명의 빈도가 보고되고 있는 데 빈도의 현저한 감소뿐 아니라 연령분포, 선행임신과 발병간의 기간, 환자의 산과력 및 임신력, 지속성 임신성 융모종양으로 발전하는 위험 군의 분포에 현저한 차이가 있었다[5]. 정상임신과 포상기태임신이 동 반된 쌍태임신은 임신 20,000 에서 100,000 건당 1 건의 빈도로 보고되 고 있다[1].

태아와 동반하는 포상기태임신은 한 쪽은 정상태아와 태반을 가지고 다른 쪽은 포상기태로 발전하는 두 개의 다른 수태산물에서 유래한다 [6]. 정상임신과 이배체 완전포상기태의 쌍태임신의 빈도는 비교적 드 물지 않은 편으로 2006년 Niemann 등[7]은 이배체 포상기태의 5\%가
정상태아와 공존하는 쌍태임신이라고 보고했다. 포상기태와 정상태아 가 공존하는 경우는 다음과 같이 구분할 수 있는데 완전포상기태와 정 상태아가 동반된 경우, 부분포상기태와 정상태아의 쌍태임신, 정상 태 아 단독임신이면서 부분포상기태 변성이 있는 경우, 정상태아와 완전 포상기태의 태반 모자이시즘이 있는 경우이다. 정상태아가 있는 경우 포상기태의 종류보다는 태아의 핵형이 더 중요한 의미를 가지며 염색 체분석을 위해 양수천자나 융모막융모생검을 시행한다[8].

그러나 이러한 검사들은 침습적이고 결과가 나올 때까지 시간이 걸 린다. 본 증례에서는 지속적인 질출혈이 있어 태아와 산모의 상태를 빨 리 확인하고 적절한 치료를 요하는 상황이었기 때문에 골반자기공명영 상 촬영을 시행하였고, 태아와 포상기태의 위치를 분명히 확인하여 빠 르고 적절한 치료방침을 수립할 수 있었다.

생존태아와 공존하는 포상기태가 진단되면 임신을 지속시킬 것인 지 중단할 것인지에 대한 고민을 해야 하는데 이는 태아의 이상 유 무, 모체의 합병증, 기태의 악성화 가능성을 고려해서 결정해야 한다. Vejerlev [6]의 보고에서 진단 즉시 임신을 종결시킨 경우는 19.2\%, 임 신을 유지하는 경우 9.2\%에서 지속성 임신성 융모종양으로 진행하는 것으로 나타났다. 2002년 Sebire 등[8]은 임신을 종결하지 않은 환자 중 $21 \%$, 임신을 종결한 경우에는 $16 \%$ 에서 지속성 임신성 융모종양으 로 인한 항암요법을 시행했다고 보고했는데 통계적으로는 두 군 간의 유의한 차이가 었다.

1991년 Vejerlev [6]은 1903년부터 1989년까지의 문헌고찰을 통해 태아의 기형과 세포유전학적 이상이 없는 태아와 공존하는 113 건의 포상기태를 연구였는데 87명이 임신을 유지하였고 그중 59.8\%인 52 명이 28주까지 임신을 유지하였다. 질출혈이 53\%, 임신중독증이 $35 \%$ 에서 동반되었고 이로 인해 각각 $17 \%, 15 \%$ 에서 임신이 종결되었다. 28주 이전에 분만한 경우 태아는 생존하지 못했지만 그 이후에 태어난 경우 태아의 생존율은 $69.2 \%$ 이었다. Steller 등[1]은 임신 초기에 발견 되면 치료적 임신중절을 신중히 고려해야 하지만, 태아의 생존가능성 이 높은 임신 주수에 진단되었다면 임신을 유지시키는 것이 합리적이 라고 하였다. 실제로 대부분 임신을 종결하지만 그 위험성에도 불구하 고 임신지속을 원하는 경우가 늘어나는 추세이다.

본 증례에서는 질출혈이 계속 지속되었고, 자궁이 주수에 비해 많이 커져 있는 상태로 초음파와 골반자기공명영상 촬영상 포상기태 조직이 자궁의 아래쪽에서 자궁 입구를 완전히 덮고 있으며 정상 임신낭보다 휠씬 크게 위치하고 있었다. 태아의 외형적 이상은 관찰되지 않았으나 질출혈이 지속되고 포상기태 조직의 위치와 크기로 미루어 임신을 유 지하는 것은 산모에게 위험할 수 있겠다는 판단하에 임신을 종결하게 되었다.

완전포상기태의 제거 후 $15 \%$ 의 환자에서 자궁침윤을 보이고 $4 \%$ 에 서 전이를 보인다. 부분포상기태에서는 $2 \%-4 \%$ 에서 지속성 임신성 융 모종양이 발생하는 것으로 알려져 있다[9]. 따라서 국소 침윤 및 원격 전이를 막아 예후를 향상하기 위해 지속성 융모종양으로의 진행 가능 성이 높은 고위험군을 분류해서 악성화의 증거가 없어도 예방적 항암 요법을 시행해왔다. 완전포상기태의 경우 기태 제거 전 인간 융모생식 


\section{KOREAN JOURNAL OF OBSTETRICS \& GYNECOLOGY}

Hye-In Sung, et al. Complete H-mole with coexistent fetus

샘자극호르몬 수치가 $100,000 \mathrm{mUU} / \mathrm{mL}$ 이상인 경우, 재태연령보다 자 궁이 더 큰 경우, $6 \mathrm{~cm}$ 이상의 난포막황체낭이 있는 경우 고위험군으 로 분류된다. 특히 융모생식샘자극호르몬 값이 높은 군에서 항암화학 요법치료를 받는 경우가 현저히 많았다[10].

1994년 Steller 등[1]은 태아가 존재하지 않는 완전포상기태에서는 $15 \%$ 에서 지속성 임신성 융모종양으로 진행하는 반면 태아가 공존하 는 완전포상기태임신에서 지속성 임신성 융모종양으로 진행하는 빈도 가 $55 \%$ 로 유의하게 높다고 보고했다. 또한 흡입소파술 전의 융모생식 샘자극호르몬 수치가 높을수록 지속성 임신성 융모종양으로 진행하는 확률이 높다고 하였다. 이는 정상태아와 생존태아가 동반된 쌍태임신 에서 아마도 단일 임신에 비해 더 높은 침윤성을 가지며 진단과 치료가 적적히 이루어지지 않기 때문이라고 추측하였다. Niemann 등[7]은 태 아와 공존하는 포상기태에서 지속성 임신성 융모종양의 발생률을 $25 \%$ 로 이는 태아가 존재하지 않는 단독 포상기태에서 지속성 임신성 융모 종양의 발생률과 차이가 없다고 보고하였다.

본 증례는 태아와 공존하는 완전포상기태임신으로, 재태연령에 비해 자궁이 커져 있었으며 수술 전 시행한 인간 융모생식샘자극호르몬 수 치가 $545,000 \mathrm{mlU} / \mathrm{mL}$ 로 현저히 높았기 때문에 고위험군으로 판단하 여 예방적 항암 화학 요법을 시행하였고 현재까지 부작용은 없다.

태아와 동반한 포상기태임신은 매우 드물기 때문에 진단이 어렵고 치료방법과 임신 유지에 대한 명확히 정립된 지침이 부족하여 논란이 있는 상태이다. 초음파검사가 진단에 중요한 역할을 하지만 검사자의 경험과 숙련도에 따른 차이가 있다. 포상기태임신을 임신 제1삼분기에 진단하는 확률은 33\%-44\% 정도이며 완전포상기태는 $58 \%-79 \%$, 부 분포상기태는 29\%-41\% 정도이다[11]. 태아와 동반하는 포상기태임신 에서의 진단율은 이보다 낮을 것으로 예상된다.

본 증례에서도 개인병원에서 정상 단태아임신으로 진단하에 정규 산 전 진찰을 시행하였고, 첫 번째 임신 때보다 임신과다구토 증세가 심하 고 배가 더 많이 불러왔으나 특별히 이상이 있다고 생각하지는 않았 고, 임신 10 주부터 질출혈이 있었으나 절박유산으로 추측하였다. 임신 13주에 본원에서 시행한 초음파검사상 정상태아와 자궁강 내부의 덩 어리가 관찰되었으나 태반의 종양이나 부분포상기태, 기타 자궁내의 종괴나 출혈과의 구분이 확실치 않아 골반 자기공명영상 촬영을 시행 하였다.

자기공명영상은 뛰어난 대조 해상도를 제공하면서도 이온화 방사선 을 제공하지 않으며, 하나 이상의 많은 단면에서 영상화가 가능하다. 또한 큰 관찰영역을 제공함으로써 초음파와는 다른 방식으로 골반 내 부의 정보를 제공한다. 자기공명영상은 현재까지 알려진 생물학적 위 험성이 없으며, 자기공명영상을 임신한 여성에서 시행하는 것이 임상 적으로 유해한 영향을 미친다는 증거는 현재까지 없다[12]. 그러므로 산과적 처치나 수술 전 자기공명영상을 통한 태아상담과 산전상담이 의사결정에 중요한 역할을 할 수 있으리라고 생각된다.

초음파가 초기 진단에 중요한 검사법이지만 자기공명영상도 포상기 태의 발견과 질병의 진행 정도를 진단하는 데 중요한 역할을 한다. 완 전포상기태는 T2 강조영상에서 자궁강을 확장시키는 많은 고신호강
도의 낭성 공간을 갖는 비균질한 종괴로 보인다. 자기공명영상 촬영으 로 기태 조직의 정확한 위치 및 크기를 확인할 수 있고 기태 조직과 자 궁 근층 사이의 접합부위의 침윤여부도 확실히 알 수 있다. 자궁외 조 직의 침범을 확인할 수 있으며 침윤성기태나 태반 종양을 감별할 수 있 다. 더불어 태아와 동반된 포상기태임신에서는 포상기태 조직과 정상 태반과의 분명한 경계, 탯줄이 정상태반과 연결되었는지 포상기태와 연결되었는지의 확실한 증거를 알 수 있다[13]. T2 강조 영상에서 양수 와 태반 조직은 고신호를 나타내고, 이는 다른 태아의 연부 조직과 잘 구분된다. T2 강조 영상에서 출혈은 저신호를 나타낸다. 이를 바탕으로 완전포상기태와 부분포상기태, 태반의 종양이나 침윤성 기태, 태반 출 혈이나 태반조기박리, 자궁근종 등과의 감별이 가능하다. 태아 고속자 기공명영상촬영을 함께 시행한다면 태아의 기형 여부도 알 수 있으며 적절한 산전상담을 할 수 있다. 특히 모체의 합병증이 동반된 경우라면 영상에서 얻은 정보를 바탕으로 빠른 치료방침을 수립하는 데 도움이 될 것이며, 임신을 적극적으로 유지하고 싶어 하는 경우라면 유전학적 검사와 동반하여 더 유용한 정보를 얻을 수 있을 것으로 생각된다.

본 증례에서도 자기공명영상을 통해 포상기태조직과 분명히 구분되 는 정상태아와 정상태반 조직을 관찰할 수 있었다. 자궁근층이나 주변 조직으로의 침윤은 관찰되지 않았다. 자궁의 종양이나 태반의 종양, 출 혈은 배제되었다. 이를 바탕으로 흡입소파술을 시행하였고, 조직병리 학적 검사 결과 역시 수술 전 미리 예측했던 정상임신과 완전포상기태 가 동반된 쌍태임신으로 확진되었다.

저자들은 임신 13 주에 자기공명영상 결과를 바탕으로 정상태아와 포상기태가 동반하는 쌍태임신을 진단하였고 예후와 위험성에 대한 충 분한 설명과 상의 후 태아의 염색체검사 등의 추가적인 검사 없이 임신 을 종결시키기로 결정하였다. 수술 전 혈청 인간 융모생식샘자극호르 몬 수치가 $545,000 \mathrm{mU} / \mathrm{mL}$ 로 현저히 높았기 때문에 임신 종결 후 예 방적 항암 화학 요법을 시행하였으며 현재 융모생식샘자극호르몬 수치 추적관찰 중이다.

\section{감사의 글}

이 논문은 2011년도 충북대학교 학술연구지원사업의 연구비 지원에 의하여 연구되었음(This work was supported by Chungbuk National University Grant in 2011).

\section{References}

1. Steller MA, Genest DR, Bernstein MR, Lage JM, Goldstein DP, Berkowitz RS. Natural history of twin pregnancy with complete hydatidiform mole and coexisting fetus. Obstet Gynecol 1994;83:35-42.

2. Novick MK, Dillon EH, Epstein NF. AJR teaching file: pregnant 


\title{
KOREAN JOURNAL OF OBSTETRICS \& GYNECOLOGY
}

\author{
KJOG Vol. 55, No. 6, 2012
}

woman with vaginal spotting, nausea, and vomiting. AJR Am J Roentgenol 2010;194:S79-82.

3. Wee $L$, Jauniaux E. Prenatal diagnosis and management of twin pregnancies complicated by a co-existing molar pregnancy. Prenat Diagn 2005;25:772-6.

4. Smith HO, Wiggins C, Verschraegen CF, Cole LW, Greene HM, Muller $C Y$, et al. Changing trends in gestational trophoblastic disease. J Reprod Med 2006;51:777-84.

5. Kim SJ, Lee C, Kwon SY, Na YJ, Oh YK, Kim CJ. Studying changes in the incidence, diagnosis and management of GTD: the South Korean model. J Reprod Med 2004;49:643-54.

6. Vejerslev LO. Clinical management and diagnostic possibilities in hydatidiform mole with coexistent fetus. Obstet Gynecol Surv 1991:46:577-88.

7. Niemann I, Petersen LK, Hansen ES, Sunde L. Predictors of low risk of persistent trophoblastic disease in molar pregnancies. Obstet Gynecol 2006;107:1006-11.

8. Sebire NJ, Foskett M, Paradinas FJ, Fisher RA, Francis RJ, Short
$D$, et al. Outcome of twin pregnancies with complete hydatidiform mole and healthy co-twin. Lancet 2002;359:2165-6.

9. Garner EI, Goldstein DP, Feltmate CM, Berkowitz RS. Gestational trophoblastic disease. Clin Obstet Gynecol 2007;50:112-22.

10. Menczer J, Modan M, Serr DM. Prospective follow-up of patients with hydatidiform mole. Obstet Gynecol 1980;55:346-9.

11. Fowler DJ, Lindsay I, Seckl MJ, Sebire NJ. Routine pre-evacuation ultrasound diagnosis of hydatidiform mole: experience of more than 1000 cases from a regional referral center. Ultrasound Obstet Gynecol 2006;27:56-60.

12. Shellock FG, Kanal E. Policies, guidelines, and recommendations for MR imaging safety and patient management. SMRI Safety Committee. J Magn Reson Imaging 1991;1:97-101.

13. Wu TC, Shen SH, Chang SP, Chang CY, Guo WY. Magnetic resonance experience of a twin pregnancy with a normal fetus and hydatidiform mole: a case report. J Comput Assist Tomogr 2005;29:415-7.

\section{자기공명영상으로 진단한 태아와 동반된 완전포상기태}

${ }^{1}$ 충북대학교병원 산부인과, ${ }^{2}$ 충북대학교 의학연구소

성혜인, 신영옥 ${ }^{1}$, 연현경 ${ }^{1}$, 이오영 ${ }^{1}$, 정은환 ${ }^{12}$

태아와 동반한 포상기태임신은 임신 20,000 에서 100,000 건당 한 건으로 매우 드물기 때문에 진단이 어렵고 치료방법과 임신 유지에 대한 명확히 정립된 지침이 부족하여 논란이 있다. 저자들은 골반 자기공명영상으로 임신 13 주에 태아와 포상기태가 공존하는 쌍태임신 을 진단하였고 임신 종결 후 예방적 항암화학요법을 시행한 1예를 경험하였기에 간단한 문헌고찰과 함께 보고한다.

중심단어: 포상기태, 쌍태임신, 자기공명영상 